\title{
The Biocompatibility of Sodium Lauryl Sulphate on Developing Zebrafish Embryos*
}

\author{
Sodyum Lauril Sülfatın Gelişmekte Olan Zebra Balığı Embriyolarında \\ Biyouyumluluğu
}

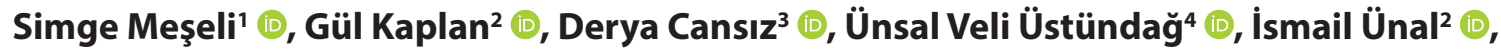 \\ Ebru Emekli-Alturfan ${ }^{5}$ (D), Funda Yanıkoğlu ${ }^{6}$ (i), Dilek Tağtekin ${ }^{1}$ (C)
}

\begin{abstract}
'Department of Restorative Dentistry, Faculty of Dentistry, Marmara University, Istanbul, Turkey ${ }^{2}$ Department of Biochemistry, Institute of Health Sciences, Marmara University, İstanbul, Turkey

${ }^{3}$ Department of Biochemistry, Faculty of Medicine, Istanbul University-Cerrahpasa, Istanbul, Turkey

${ }^{4}$ Department of Biochemistry, Faculty of Medicine, Istanbul Medipol University, Istanbul, Turkey

${ }^{5}$ Department of Basic Medical Sciences, Biochemistry, Faculty of Dentistry, Marmara University, İstanbul, Turkey

${ }^{6}$ Department of Restorative Dentistry, Faculty of Dentistry, Istanbul Kent University, Istanbul, Turkey
\end{abstract}

ORCID ID: S.M. 0000-0002-2970-658X; G.K. 0000-0003-4477-5708; D.C. 0000-0002-6274-801X; Ü.V.ü. 0000-0003-0804-1475; I.Ü. 0000-0002-8664-3298; E.E.A. 0000-0003-2419-8587; F.Y. 0000-0001-5708-1030; D.T. 0000-0002-2675-1764

Cite this article as: Meseli S, Kaplan G, Cansiz D, Ustundag UV, Unal I, Emekli-Alturfan E, Yanikoglu F, Tagtekin D. The biocompatibility of sodium lauryl sulphate on developing zebrafish embryos. Experimed 2021;11(2): 67-72.

\begin{abstract}
Objective: As an anionic surfactant, sodium lauryl sulphate (SLS), is used as an emulsifying agent in toothpastes as well as many different household cleaning products. Many toothpastes contain SLS and it is responsible for the formation of foam when brushing. However SLS may also irritate sensitive teeth and gums. Lipid peroxidation (LPO) is defined as an autoxidation process that is induced through the attack of free oxygen radicals leading to oxidative stress in the pathophysiology of various diseases. LPO causes the formation of highly reactive products including different aldehydes, ketones, and alkanes serving as biomarkers of LPO. In our study we aimed to expose zebrafish embryos to SLS and determine LPO in SLS exposed zebrafish embryos.
\end{abstract}

Material and Method: Zebrafish embryos that were dividing normally and which had spherical shapes were chosen and they were exposed to SLS both in low and high concentrations in well plates for 72 hours. Rates of mortality and hatching were determined. The levels of malondialdehyde were evaluated using the Yagi's method as the end products of LPO in the form of thiobarbituric acid reactive substances.

Results: Our findings showed LPO increased significantly in both low SLS $(p<0.05)$ and high dose SLS $(p<0.05)$ exposed zebrafish embryos when they were compared to the control group.

Conclusion: It may be suggested that LPO is an early indicator of exposure to SLS during embryogenesis and further studies are required to confirm this finding.

Keywords: Sodium lauryl sulphate, toothpaste, lipid peroxidation, zebrafish embryos

\section{öz}

Amaç: Sodyum lauril sülfat (SLS), ev temizlik ürünleri ve diş macunlarında emülsifiye edici temizlik maddesi olarak kullanılan anyonik bir yüzey aktif maddedir. Birçok diş macunu fırçalarken köpük oluşumuna yol açan SLS içerir. Ancak SLS hassas diş ve diş etlerini tahriş edebilir. Lipid peroksidasyonu (LPO), çeşitli hastalıkların patofizyolojisinde oksidatif strese yol açan serbest radikallerin saldırısı ile başlatılan bir otooksidasyon sürecidir. LPO, LPO'nun biyobelirteçleri olarak görev yapan farklı aldehitler, ketonlar, alkanlar dahil olmak üzere reaktif ürünlerin oluşumuna neden olur. Çalışmamızın amacı, SLS'ye maruz kalan zebra balığı embriyolarında oluşan LPO'yu değerlendirmektir.

Gereç ve Yöntem: Normal olarak bölünen küresel embriyolar, 72 saat boyunca plaka kuyucuklarında düşük ve yüksek dozda SLS'ye maruz bırakılmıştır. Mortalite ve kuluçkadan çıkma oranları belirlenmiştir. Tiyobarbitürik asit reaktif maddeler olarak LPO'nun son ürünü olan malondialdehit (MDA) düzeyini belirlemek için Yagi yöntemi kullanılmıştır.

Bulgular: Bulgularımız, hem düşük SLS $(p<0,05)$ hem de yüksek doz SLS'ye $(p<0,05)$ maruz kalan zebra balığı embriyolarında kontrol grubu ile karşılaştırıldığında LPO'nun önemli ölçüde arttığını göstermiştir.

Sonuç: LPO'nun embriyogenez sırasında SLS'ye maruz kalmanın erken bir göstergesi olduğu öne sürülebilir ve bu bulguyu doğrulamak için farklı çalışmaların yapılması gerektiği düşünülmektedir.

Anahtar Kelimeler: sodyum lauril sülfat, diş macunu, lipit peroksidasyon, zebra balığı embriyosu

*The research was presented as an online oral presentation in the $3^{\text {rd }}$. International Caries Prevent Symposium, Istanbul, 2020. 


\section{INTRODUCTION}

Detergents are products that are widely used by humans in various forms to provide hygiene and prevent microorganisms (1). It can be found in various forms such as cleaning, medical, cosmetic, and industrial products (2). Sodium lauryl sulphate (SLS) is a non-volatile, water-soluble, anionic surfactant commonly used in detergents. SLS, which can be produced naturally or synthetically, is found in content levels between $0.01-50 \%$ in cosmetic products and $1-30 \%$ in cleaning products (2-6). SLS is added to toothpastes due to its antibacterial effects and accounts for between $0.5-2 \%$ of weight in toothpastes (Table 1 ) (7).

Table 1: SLS Containing products (2-7).

\begin{tabular}{lc}
\hline Product & Rate of SLS \% \\
\hline Cleaning products & $1-30$ \\
\hline Cosmetic products & $0.01-50$ \\
\hline Toothpastes & $0.5-2$ \\
\hline
\end{tabular}

Toothpastes are used as aids for tooth brushing and are indispensable products that provide personal oral hygiene.

Various chemical substances were added to the chemical content of toothpastes over time, which were made from a mixture of pumice and ash between 3000-5000 BC (7). The general content of toothpastes is shown in Table 2.

Table 2: Content of toothpaste (7).

\begin{tabular}{lc}
\hline Content of Toothpaste & $\%$ \\
\hline Abrasives & $20-40$ \\
\hline Water & $20-40$ \\
\hline Moisturizers & $20-40$ \\
\hline Detergents & $1-2$ \\
\hline Binding agents & 2 \\
\hline Sweeteners & 2 \\
\hline Therapeutic agents & 5 \\
\hline Colorant and preservatives & 1 \\
\hline
\end{tabular}

Manufacturers add abrasives, thickeners, moisturizers, preservatives, detergents and active agents to the content of toothpastes to increase the effect of fluoride, remove stains on teeth and combat dental plaque (8). Detergents and surfactants in toothpastes are substances which have cleansing and antibacterial effects due to their hydrophilic and hydrophobic properties. The most common detergent used in toothpastes is SLS $\left(\mathrm{C}_{12} \mathrm{H}_{25} \mathrm{NaO}_{4} \mathrm{~S}\right)$. Its inclusion in the content of toothpastes started with the development of synthetic surfactants after World War II (7-9). Due to chemical content of toothpastes, biocompatibility also needs to be searched.

All chemicals have toxic doses. In fact, many foods with chemical content are classified as toxic. For example, table salt is considered to be moderately toxic with $\mathrm{LD}_{50}=3000 \mathrm{mg} / \mathrm{kg}$. Many toxicity studies have been conducted on SLS (10-13). Lethal concentrations based on animal experimental results are shown in Table 3.

In spite of there being few in vivo clinical studies, there are many in vitro studies on animals in literature to evaluate toxicity. Among the model organisms used for the toxicological evaluation of chemicals and drugs, zebrafish have recently been accepted as the gold standard $(14,15)$. The Zebrafish is a $4-6 \mathrm{~cm}$ long fresh water fish, has $84 \%$ of human disease genes, and can breed a large number of embryos at the same time with external fertilization. The development of externally fertilized zebrafish embryos is very quick and the transparency of the embryo and the larvae allows them to be observed and to be manipulated easily in all development periods. Thus, they are considered more advantageous than common mammalian organism models (example: mouse). Embryotoxicity tests using zebrafish embryos is quite fast and simple method to evaluate the toxicity of many substances during embryogenesis $(16,17)$.

Lipid peroxidation (LPO) is a detrimental autoxidation process that is induced through the attack of free oxygen radicals leading to oxidative stress in the pathophysiology of various diseases. In the LPO process, free radicals attack phospholipids or polyunsaturated fatty acids of cellular or subcellular component membranes. This causes the formation of highly reactive products including different aldehydes, ketones, and alkanes serving as biomarkers of LPO (18). The purpose of our study was to evaluate the possible toxic effects of SLS on developing zebrafish embryos.

Table 3: The lethal concentrations of SLS in different model organisms (2).

Acute Toxicity Acute Toxicity Oral Exposure Dermal Exposure in in Rats
Acute Toxicity

Inhalation

in Rats
Lowest-observedadverse-effect in Rats
Aquatic Toxicity in Fish (96 hpf) 


\section{MATERIAL AND METHOD}

Research was carried out in Marmara University Basic Medical Sciences Department. Adult zebrafish were used for the research. Male and female (2:1) zebrafish were kept in an aquarium rack system at $28^{\circ} \mathrm{C}$ under a $14 / 10$ light/dark cycle (Figure 1). Fertilized eggs were collected and embryos were rinsed under water several times before used. Normally dividing, spherical embryos were exposed to a low dose $(0.01 \mathrm{mg} / 10 \mathrm{ml})$ and a high dose $(0.04 \mathrm{mg} / 10 \mathrm{ml})$ of SLS solutions. E3 Medium solution was placed in well plates for the control group. In total, 180 embryos were used. Each exposure group was prepared as 3 replicates in 24-well plates having 20 embryos in each of them. They were monitored to evaluate their development and the images of malformations were recorded by using a stereomicroscope (Zeiss Discovery.V8). Mortality and hatching analyses were also carried out every $24 \mathrm{~h}$. Hatching rate is defined as the ratio of hatched embryos to the whole number of alive embryos in each well. Each day all the exposure solutions used in the study were changed and they were replaced with fresh solutions. At the end of 72 hours post-fertilisation (hpf) the exposure period ended and the zebrafish embryos were washed several times using water.

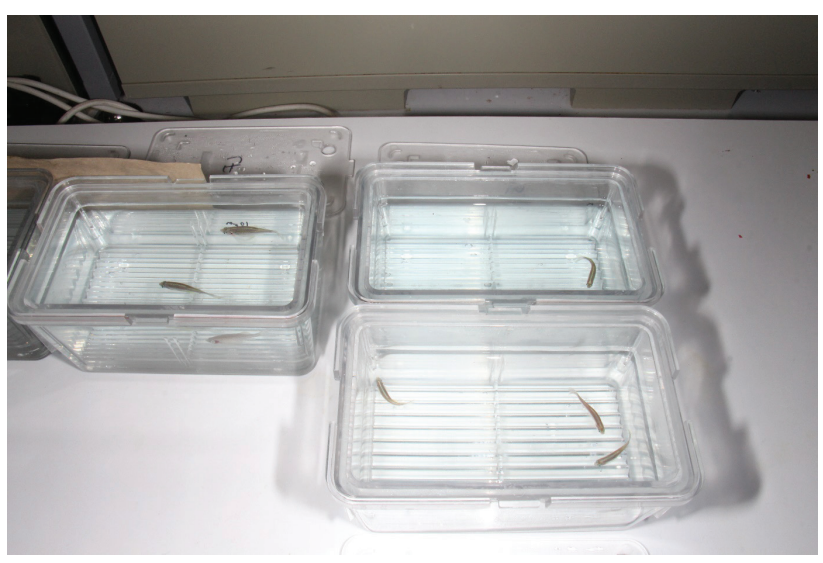

Figure 1: Breeding of zebrafish

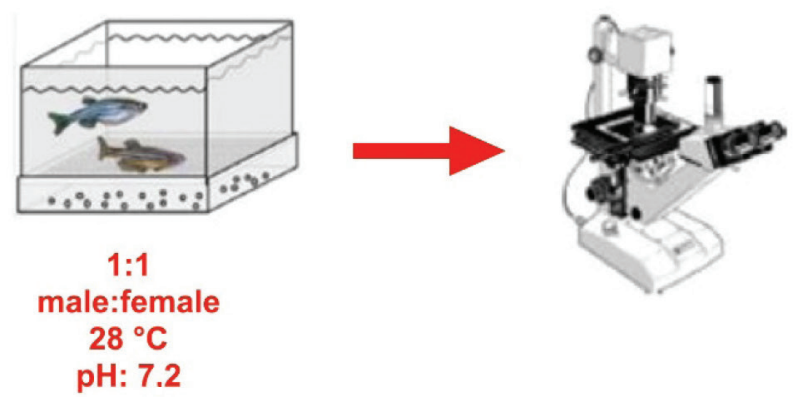

The zebrafish housing, matching, exposure systems and the stereomicroscope setup used to examine the development are given in Figure 1, and the experimental setup is given in Figure 2.

\section{Biochemical analyses}

In order to determine the biochemical parameters, zebrafish embryos at $72 \mathrm{hpf}$ were used. At the end of 72 hours, the zebrafish embryos in each pool were homogenized in $1 \mathrm{~mL}$ PBS, and this was followed by a brief centrifugation. This procedure was prepared as replicate pools of zebrafish embryos. For the analyses of protein levels and LPO, the supernatants was used.

\section{Determination of Total Proteins}

In order to evaluate the level of total proteins in the supernatants by using albumin as the standard, the Lowry method was applied (19). In this method, the reaction of alkaline proteins with copper ions was followed by their reduction by the Folin reagent. Using a spectrophotometer, the absorbances of the agents produced was evaluated at $500 \mathrm{~nm}$. The results were calculated to express the numeric values per protein.

\section{Determination of Lipid Peroxidation (LPO)}

Malondialdehyde (MDA) is the end product of LPO and the MDA levels in the supernatants were evaluated as thiobarbituric acid reactive substances (TBARS) using Yagi's method (20). In this assay, the extinction coefficient was used as $1.56 \times 10^{5}$ $\mathrm{M}^{-1} \mathrm{Cm}^{-1}$. At the end of the assay LPO levels were given as nmol $\mathrm{MDA} / \mathrm{mg}$ protein, in terms of MDA equivalents.

\section{Statistical analysis}

GraphPad 9 was used to evaluate the differences between the low dose exposed SLS, high dose exposed SLS groups and the control group. First one-way analysis of variance (ANOVA) analysis was applied and this was followed by Dunn's multiple comparison test in order to evaluate the differences between the two groups. A value of $p<0.05$ was considered as statistically significant.

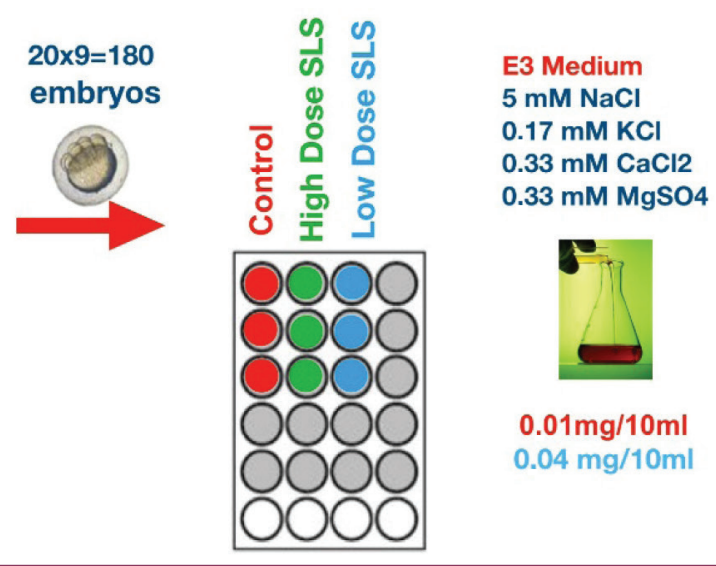

Figure 2: The schematized experimental setup. 


\section{RESULTS}

The representative images of the zebrafish embryos at $48 \mathrm{hpf}$ are given in Figure 3. Yolk sac edema were observed in both the low dose exposed SLS and high dose exposed SLS groups whereas spine curvature was observed in the high dose exposed SLS group. High dose SLS exposed zebrafish embryos were found to have an increased mortality rate which was significantly higher than the group exposed to the low dose of SLS as well as the control group ( $p<0.05)$ (Figure 4). A delayed hatching period was observed in the group of zebrafish embryos exposed to a high dose SLS compared to the SLS group exposed to a low dose and the control group $(p<0.05)$. There was no significant difference between the group exposed to a low dose SLS and the control group ( $p>0.05$ ) (Figure 5).
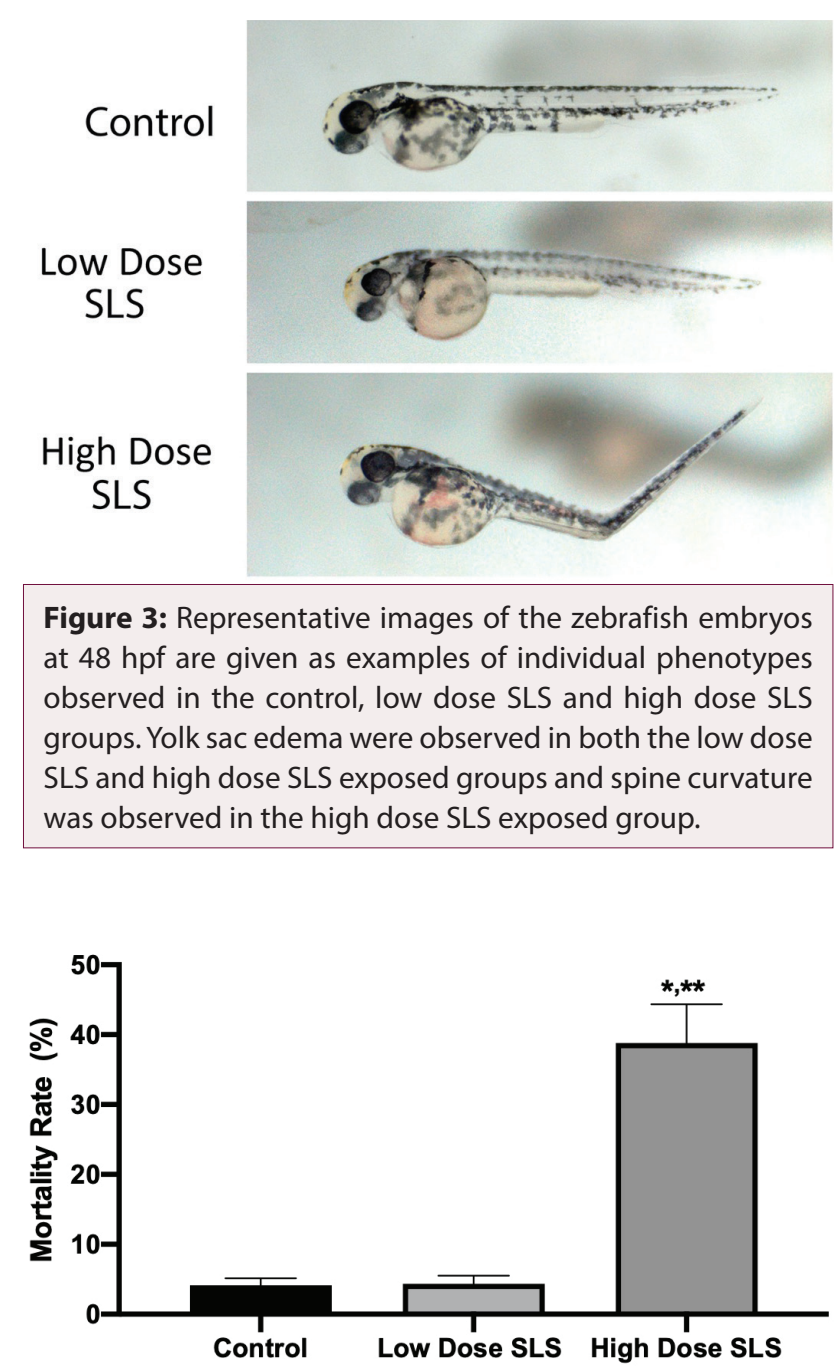

Figure 4: Mortality rates (\%) of the control, low dose SLS and high dose SLS groups at 72 hpf. Values are given as mean \pm standard deviation. ${ }^{*} \mathrm{p}<0.05$ Significantly different than the control group; ${ }^{* *} \mathrm{p}<0.05$ Significantly different than the low dose SLS group.

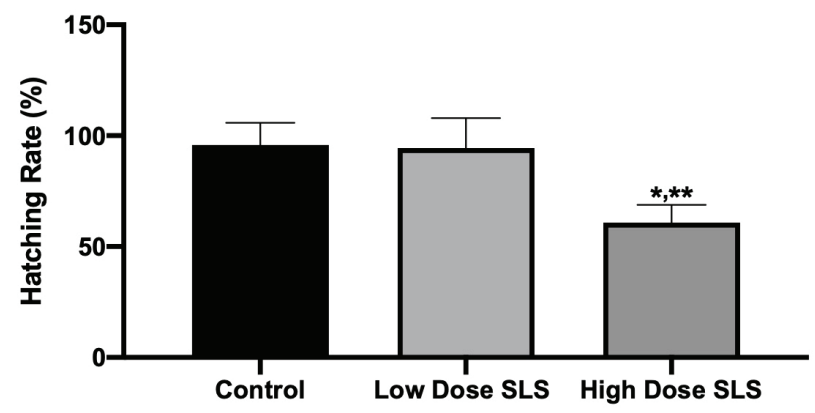

Figure 5: Hatching rates (\%) of the control, low dose SLS and high dose SLS groups at 72 hpf. Values are given as mean \pm standard deviation. ${ }^{*} \mathrm{p}<0.05$ Significantly different than the control group; ${ }^{* *} \mathrm{p}<0.05$ Significantly different than the low dose SLS group.

\section{Lipid Peroxidation}

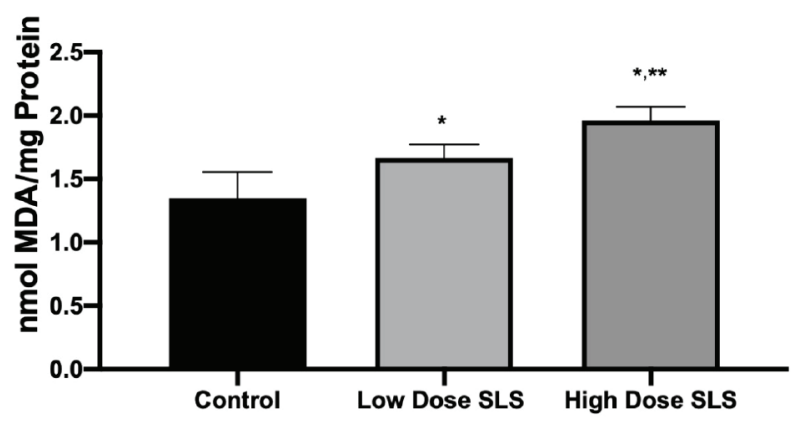

Figure 6: MDA levels as the end product of LPO, of the control, low dose SLS and high dose SLS groups at $72 \mathrm{hpf}$. Values are given as mean \pm standard deviation. ${ }^{*} \mathrm{p}<0.05$ Significantly different than the control group; ${ }^{* *} \mathrm{p}<0.05$ Significantly different than the low dose SLS group.

Our results showed that LPO increased significantly in both low $(p<0.05)$ and high dose exposed SLS $(p<0.05)$ zebrafish embryos when compared with the control group. Moreover LPO levels of the high dose exposed SLS zebrafish embryos increased significantly when compared with the low dose exposed SLS group $(p<0.05)$ (Figure 6).

\section{DISCUSSION}

Recently, the toxicity of toothpaste ingredients has been a matter of concern. Products, which are extremely useful at appropriate doses, may be harmful in overdose. There have been many in vitro studies that were conducted to determine the toxicity of toothpaste ingredients. According to the results of these studies, although the concentration of the ingredients included in the toothpaste is low, the same ingredients can be taken into the body through drinking water, food, environment and other personal care products and stored in various organs and there is a possibility that their levels might increase. 
Detergents are substances that are added to toothpaste for cleaning and antibacterial effects due to their hydrophilic and hydrophobic properties. SLS, which is the most used detergent in toothpastes, is thought to have some side effects on the gum as well as adverse effects in patients with recurrent aphthous ulcers. SLS causes oral mucosal desquamation $(21,22)$. Elimination of the protective mucin surface layer induced by SLS reduces the resistance of the oral mucosa (23). It has been shown that there is a relationship between increased oral desquamation and toothpaste use (24-26).

In the study conducted by Shim et al., it was stated that the duration of the ulcer and the pain score decreased significantly during the period when toothpaste containing SLS was used (22). Different studies have shown that ulceration and inflammation are caused by SLS. SLS also causes significant histological changes in the buccal epithelium, e.g. hyperkeratosis, acanthosis, basal cell hyperplasia, and increased epithelial thickness (27). In an in vivo study conducted by Tadin et al. (2019), which examined the effects of SLS on human buccal epithelial cells, it was found to alter nuclear morphology, which in turn increases epithelial thickness (28).

Although there is a limited number of studies investigating the effects of triclosan, fluoride and silica nanoparticle contents of toothpastes on zebrafish embryos, there is no study in the literature examining the effect of SLS content on zebrafish embryos (29-36). Our study is the first research to be done in this way. The toxic effects of the chemical content of toothpastes have been highly debated recently. Zebrafish, which has been accepted as the gold standard in toxicity studies, will be useful in the toxicity analysis of toothpastes due to the advantages of producing a large number of embryos (which will make the study more statistically reliable) and the examination of the differences in developmental stages.

Short-term SLS exposure was shown to result in the modification of morphology and cell composition of the gill apparatus in ornate wrasse (37). Because of their physiological and anatomical characteristics, fish are very sensitive to the toxic effects of many compounds. Our study is the first research to evaluate the effects of SLS on developing zebrafish embryos. We observed an increased LPO in SLS exposed embryos. The mechanism of the toxic effects of anionic detergents has been evaluated in previous studies $(37,38)$. Prolonged anionic detergents exposure has been shown to cause mortality in fish which might be because of hypoxia, osmotic or ionic stability loss (38). In another study, guinea pigs were exposed to nickel (Ni), SLS and a combination of the two for 7 and 14 days dermally. The exposure to Ni and SLS led to changes in enzymes and LPO in the kidneys. Moreover, exposure to Ni or SLS caused slight alterations while their combined exposure exhibited more degenerative alterations in the kidneys. The authors suggest that industrial workers who are exposed simultaneously to Ni and SLS may run the risk of having kidney damage (39).
Toothpastes have many indispensable benefits such as preventing tooth decay, repairing initial caries chemically with remineralization, removing bad mouth odors, when cleaning mechanically with a toothbrush. On the other hand, some substances in the toothpaste can enter the circulation system and be stored in various organs. In addition to the beneficial properties we have mentioned, in order to prevent harm, one should be careful about this matter, especially in children, toothpaste suitable for the age group should be used, and care should be taken not to swallow the toothpaste consciously or unconsciously in both children and adults.

Ethics Committee Approval: Since zebrafish embryos before 5 days after fertilization were used in the study, ethical approval is not required for the protocols applied, according to the European Union Directive 86/609/EEC (1986) and the Regulation on the Working Procedures and Principles of Animal Experiments Ethics Committees published in the Official Gazette No. 26220.

Author Contributions: Conception/Design of Study - E.E.A., F.Y., D.T.; Analysis and/or Interpretation - E.E.A., F.Y., D.T., S.M., G.K., D.C., U.V.U.; Drafting Manuscript - S.M., E.E.A.; Critical Revision of Manuscript - E.E.A., F.Y., D.T.; Final Approval and Accountability - E.E.A., F.Y., D.T., S.M., G.K., D.C., U.V.U.

Conflict of Interest: The authors have no conflict of interest to declare.

Financial Disclosure: The authors declared that this study has received no financial support.

Etik Komite Onayı: Çalışmada fertilizasyon sonrası 5 günden önceki zebra balığı embriyoları kullanıdığı için, Avrupa Birliği (1986) 86/609/ EEC sayılı direktifine ve 26220 sayılı Resmi Gazetede yayımlanan Hayvan Deneyleri Etik Kurullarının Çalışma Usul ve Esaslarına Dair Yönetmeliğe göre, uygulanan protokoller kapsamında etik kurul onayı gerekmemektedir.

Yazar Katkıları: Çalışma Konsepti - E.E.A., F.Y., D.T.; Veri Analizi/Yorumlama - E.E.A., F.Y., D.T., S.M., G.K., D.C., Ü.V.Ü.; Yazım - S.M., E.E.A.; İ̧̧eriğin Eleştirel İncelemesi - E.E.A., F.Y., D.T.; Son Onay ve Sorumluluk - E.E.A., F.Y., D.T., S.M., G.K., D.C., Ü.V.Ü.

Çıkar Çatışması: Yazarlar çıkar çatışması olmadığını bildirmişlerdir.

Finansal Destek: Yazarlar bu çalışmada finansal destek almadıklarını beyan etmişlerdir.

\section{REFERENCES}

1. Magny R, Auzeil N, Olivier E, Kessal K, Regazzetti A, Dutot M, et al. Lipidomic analysis of human corneal epithelial cells exposed to ocular irritants highlights the role of phospholipid and sphingolipid metabolisms in detergent toxicity mechanisms. Biochimie 2020; 178: 148-57. [CrossRef]

2. Bondi CAM, Marks JL, Wroblewski LB, Raatikainen HS, Lenox RS, Gebhardt KE. Human and Environmental Toxicity of Sodium Lauryl Sulfate (SLS): Evidence for Safe Use in Household Cleaning Products. Environ Health Insights 2015; 9: 27-32. [CrossRef]

3. Cosmetic Ingredient Review (CIR). Final report on the safety assessment of sodium lauryl sulfate and ammonium lauryl sulfate. Int J Toxicol 1983; 2(7): 1-34. 
4. Robinson VC, Bergfeld WF, Belsito DV, Hill RA, Klaassen CD, Marks $J G$, et al. Final report of the amended safety assessment of sodium lauryl sulfate and related salts of sulfated ethoxylated alcohols. Int J Toxicol 2010; 29(4): 151S-61S.

5. Proctor \& Gamble (P\&G). Safety Data Sheets. Accessed August 19, 2015. Available from: URL: http://www.pgprod- uctsafety.com/ productsafety.

6. Seventh Generation. Material Safety Data Sheets. Accessed August 17, 2015. Available from: URL: http://www.sev- enthgeneration.com/material-safety-data-sheets.

7. Lippert F. An introduction to toothpaste its purpose, history and ingredients. Van Loveren C. Toothpastes. 23. Basel: Karger; 2013. p. $1-14$.

8. Jenkins S, Andy M, Newcombe R. Triclosan and sodium lauryl sulphate mouth rinses effects on salivary bacterial counts. J Clin Periodontol 1991; 18(2):140-8. [CrossRef]

9. Herlofson BB, Barkvoll P. Oral Mucosal desquamation caused by two toothpaste detergents in an experimental model. Eur J Oral Sci 1996; 104(1): 21-6.

10. Material Safety Data Sheet: Sodium Chloride. Accessed August 20, 2015. Available from: URL: http://www.sciencelab.com/msds. php?msdsld.

11. Product Bulletin: Sodium Lauryl Sulfate. Stepan Company, Northfield, Illinois; 2012. Available from: URL: https://www.stepan.com

12. Material Safty Data Sheet: STEPANOL WA-EXTRA K. Stephan Company, Northfield, Illinois; 2006. Available from: URL: https://www. stepan.com

13. OECD Screening Information Data Set (SIDS). Sodium Dodecyl Sulfate. August 19, 2015. Available from: URL:http://www.chem. unep.ch/irptc/sids/OECDSIDS/151213.htm

14. Jia HR, Zhu YX, Duan QY, Chen Z, Wu FG. Nanomaterials meet zebrafish: Toxicity evaluation and Drug Delivery Applications. J Control Release 2019; 311-312: 301-18.

15. Scholz S, Fischer S, Gündel U, Küster E, Luckenbach T, Voelker D. The Zebrafish embryo model in environmental Risk assessment applications beyond acute toxicity testing. Environ Sci Pollut Res 2008; 15(5): 394-404. [CrossRef]

16. Chakravarty S, Sadagopan S, Nair A, Sukumaran SK. Zebrafish as an in vivo high-throughput Model for Genotoxicity. Zebrafish 2014; 11: 154-66. [CrossRef]

17. Kayhan FE, Kaymak G, Esmerduruel HE, Tartarkızılkaya Ş. Biyolojik Araştırmalarda Zebra Balığının Kullanılması ve Önemi. GBAD 2018; 7: 2.

18. Gaschler M, Stockwell B R. Lipid peroxidation in cell death. Biochem Biophys Res Commun 2017; 482(3): 419-25. [CrossRef]

19. Lowry $\mathrm{OH}$, Rosebrough NJ, Farr AL, Randall RJ. Protein measurement with the Folin phenol reagent. J Biol Chem 1951; 193(1): 265-75. [CrossRef]

20. Yagi K. Assay for blood plasma or serum. Methods Enzymol 1984; 105: 328-37. [CrossRef]

21. Hoogendoorn $\mathrm{H}$, Scholtes W. Influence of the ctivation of the lactoperoxidase System in saliva on the initiation of caries and chronic, recurrent aphthes. I. Ned Tijdschr Tandheelkd 1979; 86(1): 36-9.

22. Shim YJ, Choi JH, Ahn HJ, Kwon JS. Effect of sodium lauryl sulfate on recurrent aphthous stomatitis: a randomized controlled clinical trial. Oral Dis 2012; 18(7): 655-60. [CrossRef]

23. Siegel IA, Gordon HP. Surfactant induced alterations of permeability of rabbit oral mucosa in vitro. Exp Mol Pathol 1986; 44(2): 132-7. [CrossRef]
24. Stec IP. A possible relationship between desquamation and dentifrices. A clinical study. J Am Dent Hyg Assoc 1972; 46(1): 42-5.

25. Kowitz G, Lucatorto F, Bennett W. Effects of dentifrices on soft tissues of the oral cavity. J Oral Med. 1973; 28(4): 105-9.

26. Allen AL, Hawley $C E$, Cutright $D E$, Seibert JS. An investigation of the clinical and histologic effects of selected dentifrices on human palatal mucosa. J Periodontol 1975; 46(2): 102-12. [CrossRef]

27. Baert JH, Veys RJ. Triclosan inhibits sodium lauryl sulphate-induced changes in expression of cytokeratin genes in hamster check pouch epithelium. J Oral Pathol Med 1997; 26: 181-6. [CrossRef]

28. Tadin A, Gavic L, Govic T, Galic N, Vladislavic ND, Zeljezic D. In vivo evaluation of fluoride and sodium lauryl sulphate in toothpaste on buccal epithelial cells toxicity. Acta Odontol Scand 2019; 77: 386-93. [CrossRef]

29. Meşeli S, Yanıkoğlu F, Arslantunalı Tağtekin D. Diş Macunları Toksik Mi? Arslantunalı Tağtekin D, editör. Diş Macun ve Kremleri. 1. Baskı. Ankara: Türkiye Klinikleri; 2020. p.122-7.

30. Escarrone AL, Caldas SS, Primel EG, Martins SE, Nery LE. Uptake, tissue distribution and depuration of triclosan in the guppy Poecilia vivipara acclimated to freshwater. Sci Total Environ 2016; 560561:218-24.

31. Newton AP, Cadena SM, Rocha ME, Carnieri EG, Martinelli De Oliveira MB. Effect of triclosan (TRN) on energy-linked functions of rat liver mi- tochondria. Toxicol Lett 2005; 160: 49-59. [CrossRef]

32. Ruszkiewicz JA, Li S, Rodriguez MB, Aschner M. Is triclosan a neurotoxic agent? J Toxicol Environ Health 2017; B 20:104-17.

33. Cherednichenko G, Zhang R, Bannister RA, Timofeyev V, Li N, Fritsch EB, et al. Triclosan impairs excitation-contraction coupling and $\mathrm{Ca}^{2+}$ dynamics in striated muscle. Proc Natl Acad Sci USA 2012; 109: 14158-63. [CrossRef]

34. Etzel TM, Calafat AM, Ye X, Chen A, Lanphear BP, Savitz DA, et al. Urinary triclosan concen- trations during pregnancy and birth out- comes. Environ Res 2017; 156: 505-11. [CrossRef]

35. Yi HY, Wang ZY, Li XJ, Yin M, Wang LH, Aldalbahi A, et al. Silica nanoparticles target a Wnt signal transducer for degradation and im- pour embryonic development in zebrafish. Theranostics 2016; 6(11): 1810-20. [CrossRef]

36. Pepla E, Besharat LK, Palaia G, Tenore G, Migliau G. Nano-hydroxyapatite and its applications in preventive, restorative and regenerative dentistry: a review of literature. Ann Stomatol (Roma) 2014; 5(3):108-14.

37. Brunelli E, Talarico E, Corapi B, Perrotta I, Tripepi S. Effects of a sublethal concentration of sodium lauryl sulphate on the morphology and $\mathrm{Na}^{+} / \mathrm{K}^{+}$ATPase activity in the gill of the ornate wrasse (Thalassoma pavo). Ecotoxicol Environ Saf 2008; 71(2): 436-45. [CrossRef]

38. Lock, RAC, Van Overbeeke P. Effects of mercuryc chloride andmethylmercuryc chloride on mucous secretion in rainbow trout, Salmogairdneri Richardson. Comp Biochem Physiol 1981; 69: 6773.

39. Mathur AK, Gupta BN, Singh A, Singh S, Shanker R. Renal toxicity of nickel, sodium lauryl sulphate and their combination after dermal application in guinea pigs. Biomed Environ Sci 1993; 6(3): 231-6. 